\title{
Politics without morality and accountability: The Nkandla case from a deontological perspective
}

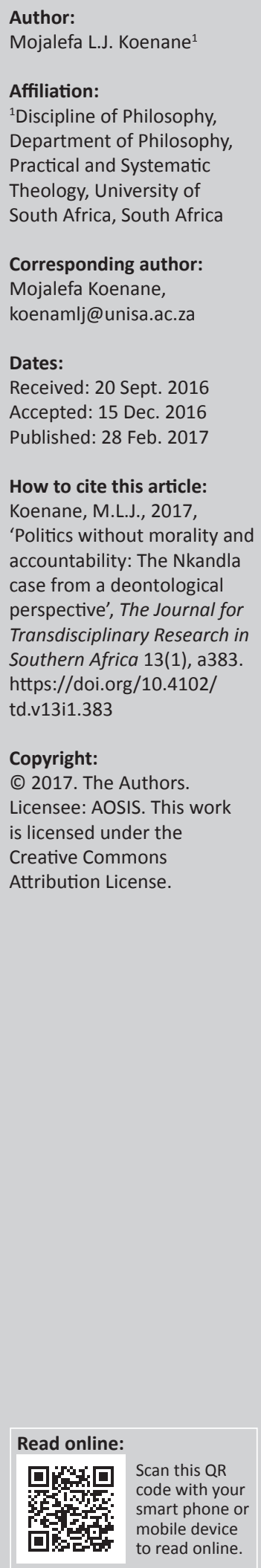

The Nkandla controversy has long dominated South African politics and has seemingly been endless. This article revisits the Nkandla issue from the perspective that it fails the Kantian categorical imperative (i.e. CI) and attempts to explain the problem of individual as well as organisational or structural corruption, in which the author contends the Nkandla controversy to be grounded. This article opens a discussion on the relevance of Kantian theory in confronting the matter of Nkandla. The author argues that Kant's moral theory should not be viewed simplistically but from a rational position of internalised moral maxims or precepts. The Nkandla project is interrogated in relation to the former Public Protector's and Minister of Police's reports on the Nkandla 'security upgrades'. It is the author's view that South Africans are demanding accountability insofar as the Nkandla project is concerned, since moral attitudes are an integral and necessary part of our everyday lives. It is the author's contention that the President and the executive have no desire to be accountable and transparent in the Nkandla matter. The aftermath of Nkandla controversy has changed the face of South Africa's political environment completely. The author further argues that holding political elites accountable should not be regarded as hostility towards those held responsible and the African National Congress as political organisation. The author also looks at the Constitutional Court ruling on this matter.

\section{Introduction}

The Nkandla controversy is currently a political cauldron on which public opinion has been expressed, thus giving an indication that the public can no longer be taken for granted by political elites. News bulletins and newspapers in South Africa are dominated by the Nkandla controversy either in the form of the love-hate relationship between President Zuma's loyalists, Cabinet Ministers (in particular the Minister of Police) and Deputies, African National Congress' uMkhonto weSizwe (that is MK) veterans and the Office of the former Public Protector Thuli Madonsela. Furthermore, opposition parties in parliament, in particular the Democratic Alliance (DA) and the Economic Freedom Fighters, are keen to pursue the matter with a hope of finding out who is accountable for authorising the exorbitant and extravagant amount of R246 million (almost 1/4 of a billion) in the so-called security upgrades at Nkandla's private home of the President. The Nkandla controversy does not seem to reach finality, not even after the President 'paid back' the money. South Africa's political situation is at a standstill since the whole focus is on Nkandla. In this article, the author attempts to understand organisational or structural corruption and its strategies of shifting blame from powerful political decision-makers to inconsequential role players. Furthermore, the author examines the confusion, which is caused by failure to separate organisational, private or personal ends and that which is in the public interest. The public need to be able to separate organisational interests; in the case of Nkandla it was difficult to draw a line between the President as the President of the country or his position as the president of the political organisation or even his capacity as a private person. In political terms, the inability to draw a line between these competing benefits constitutes conflict of interest. The ANC National Executive Committee regarded critics of how Nkandla project was handled as attacks on the organisation and on the person of President Zuma. It is the author's contention that by its very nature democracy allows for democratic processes to be scrutinised; this scrutiny is perceived by Zuma supporters as hostility towards the ANC. But some such as the former Premier and National Executive Member (NEC) Matthew Phosa has come out publicly criticising both the President and the ANC. Phosa stated that the ANC must stop protecting corruption (Eye Witness News August 21, 2014).

In her detailed report on the Nkandla 'security upgrades', the former Public Protector concluded that some but not all of the Nkandla 'security upgrades' were in her opinion 'undue personal benefit by the President and his family' (Madonsela 2014). She further posited in her 
recommendations that the President pays back a portion of the exorbitant amount of this unjustifiable expenditure incurred in the building of his private home at Nkandla (Madonsela 2014). Although the President initially resisted, he ultimately did settle the amount which was decided by the National Treasury as non-security upgrades, which was R7.8 million. Two instances of the President's reaction and defiance to the former Public Protector's correspondence and recommendations are of interest to the author. This was after the Constitutional Court $^{1}$ judgement earlier this year (Mogoeng 2016).

The author looks at three sections of the former Public Protector's closing recommendations, specifically those directed to the President and one especially directed to the Minister of Police. According to the former Public Protector, the President needed to do the following (The former Public Protector's Report on Nkandla (Madonsela 2014:48) subsection (a)):

1. To take steps with the assistance of the National Treasury and the SAPS, to determine the reasonable cost [...].

2. Pay a reasonable percentage as determined with the assistance of National Treasury [...].

3. Reprimand the Ministers involved for the appalling manner in which the Nkandla project was handled and state funds were abused.

Firstly, the President contends that because he did not ask for these security upgrades to his private dwelling, he was not going to pay back the money and claimed no knowledge about the upgrades that were taking place in his private residence (April 2, 2014). Put differently, he is defiant and he (the President) is not prepared to comply with these recommendations. Secondly, the President decided to change the terms of reference as set out by the former Public Protector. Instead of determining the reasonable percentage the President had to pay, he subsequently instructed the Minister of Police to establish whether he (the President) must pay a percentage towards the upgrades or not. The report by the Minister of Police (Nhleko 2015) came as no surprise to many when he announced that the President should not pay anything towards part of the upgrades, which were considered by the former Public Protector as non-security features. The instructions of the former Public Protector to the Minister of Police are similarly of interest to the author. Section (m) subsection (c) (2) of the former Public Protector recommendations reads thus: 'ensure that no further security measures are installed at the President's private residence [...]'. South Africans' opinions are diverse on the Nkandla security upgrades issue; some do not see any wrongdoing on the part of the President (especially his loyal supporters in KwaZulu-Natal province) and have accepted his apology, while others expressed their moral outrage and indignation ${ }^{2}$, on the same matter. This

1.The Constitutional Court is the highest court in South Africa, the decisions of which reign supreme.

2.The South African general population was interviewed on the Nkandla matter and expressed their views on social media and public setting such as radio and television stations. recommendation by the Minister of Police is problematic and considered by many as continuous undermining of the constitution. This position further sends a message to the public that the Office of the Public Protector can be undermined by those who are prepared to abuse their power-positions. However, the decision of the Constitutional Court announced on 31 March 2016 reaffirmed the findings of the former Public Protector Thuli Madonsela. Chief Justice Mogoeng announcing the unanimous decision by Constitutional Court Judges elucidated:

Certain values in the Constitution have been designated as foundational to our democracy. This in turn means that as pillarstones of this democracy, they must be observed scrupulously. If these values are not observed and their precepts are carried out conscientiously, we have a recipe for constitutional crisis of great magnitude. In a State predicament on a desire to maintain the rule of law, it is imperative that one and all should be driven by a moral obligation to ensure the continued survival of our democracy. (The Law Society Library, CCT 143/15 and CCT $171 / 15$, p. 4)

While the former Public Protector's findings were clear that the President acted unethically (2014 subsection (j) 1-7), nowhere in her report does the term corruption appear. As such, President Zuma capitalised on this aspect. According to the President since there is no mention of corruption in the former Public Protector's report, he could not be accused of corruption. Therefore, in terms of the President's interpretation, the author's viewpoint is that the South African public needs to revisit its understanding of corruption, that is, individual and structural corruption, as well as public opinion on this matter. This article adopts the following schema:

1. Defining the problem.

2. The categorical imperative as method of dealing with political situations.

3. Understanding corruption and structural corruption.

4. Applying Kantianism in the Nkandla controversy.

\section{The problem}

It is not easy to define the problem, but, in short, the author refers to it as the ethical dimension of the Nkandla decisionmaking process and its aftermath. South Africans want an explanation regarding the Nkandla project; they want to know who is responsible for what. The author contends that from an ethico-moral point of view whenever a decision is made, whoever made a decision must account for it. Furthermore, it is the author's view that political decisions must be rational, objective and non-personal. What went wrong? Who must account? It was in 2009 that South Africans and the world first heard about the Nkandla renovations which, at that time, shocked many although the amount was estimated at R60 million. The current amount is just about $1 / 4$ of a billion, which is spent on what government and some ANC members, including the National Executive Committee, Umkhonto weSizwe veterans and Zuma-cabinet loyalists, regard as 'security upgrades'. Certain actions are considered morally right, while others are said to be morally wrong; however, this particular action is viewed not only from a 
moral perspective but also from constitutional and legal perspective. Morality viewed from its relationship with the law could be understood as behaviour guided by rules; therefore, political elites need to be held accountable to the values they espouse and moral orders, which their organisation promote. Pinto, Leana and Pil (2008:686) elaborate: 'An organisation may impose processes and structures to inhibit corruption against it, but the same organization may not discourage corruption on its behalf'. Clearly, the African National Congress has allowed itself as the organisation to be compromised by failing to distance itself from the Nkandla controversy.

This basically is Kant's conception of moral obligation or duty. His compelling statement about what constitutes the good is freedom of choice, which renders individuals duty absolute but at the same time moral. Levine puts it in more lucid terms as he notes that:

The term norm refers to a standard or expected pattern of behaviour. When norms are formerly instituted and sanctioned by authority, they become rules, just as rules applied for a long enough period of time may become norms. Rules and norms take on a moral significance when their authority derives not from habit, convenience or the arbitrary decisions of governing institutions, but from their connections to an ideal of the good. The attack on rules and norms may be an attack on the good, or it may be an attack on rules perceived to be arbitrary because they are not morally conventional. (Levine 2005:3)

Rules are morally conventional when confirming to human conduct and by extension human beings are regarded as good or right. Morality then is about human efforts to be good and right, and therefore, to fend off possibility that human beings could be judged bad or wrong (2005:2). In other words, morality should not be understood as something imposed but the individual's inner efforts to be genuinely good. The three theories discussed at length are utilitarianism, deontology and virtue or character ethics. In the abovementioned work, the author further posits that ethical theories are just approaches, which serve to justify humankinds' inclinations towards a particular approach to morality and how people internalise or fail to internalise morality. Internalised morality according to the author could be viewed from two perspectives: individual morality, and organisational or structural morality. In a sense, morality is individual when individuals take charge of their own behaviour and reflect on the impact of this behaviour in relation to how their (collective) actions affect the public. Niebuhr (2001:42) contends that it is difficult to outline the attitudes and actions of classes - the author's interpretation of Niebuhr's classes is organisational or structural for the purpose of this article. The important aspect of morality in this case is that it is an extension of the self and the inner disposition. Further to that, morality is organisational or structural when the decision reflects on an organisation or institution as a whole. In this case, individuals who hold strategic positions within an organisation would collectively be held accountable for behaviour of its members or as collective try to justify actions of its leaders irrespective of what society accepts as true. The idea of collective moral responsibility is derived from the belief that an individual's moral standards are in most cases a reflection of his or her inner organisation. Put differently, an individual's moral principles affect the group. In Kritz (1995:208), Massey clarifies the idea of moral guilt by positing that moral responsibility for actions or failure to act appropriately must be established by interrogating the moral agent or at least by an attempt to determine blameworthiness of the moral agent.

It is, thus, argued that the actions of the moral agents involved in the decision-making process regarding the so-called 'security upgrades' at the President's private residence were unconcerned at least insofar as the majority of South African society is concerned. This arrogance was further displayed when the Minister of Police in his latest report on the former Public Protector's recommendation concluded that despite the extravagant spending that the remaining security upgrades must further be funded (Nhleko 2016). It is argued that Kant's ethical theory does allow us to reflect and apply it in the Nkandla matter as it affects the larger South African society. Questions that need to be answered are: What was the moral obligation on the part of all those involved? Was there a moral duty towards the entire South African society? Could the maxim of the Nkandla project be universalised?

In the next section, the author undertakes to explain the nature of political corruption from an individual's actions especially when the individual holds political power; the author, likewise ventures into collective political corruption.

\section{The relationship between individual and structural corruption}

There are times when moral responsibility is looked at from a collective perspective - that is, when morality is understood from a relationship context. Zaleznik (1970) puts it more clearly organisations empower individuals in a literal sense. He further asserts that organisations are political structures which provide opportunities and 'platforms for the expression of individual interests and motives'. In one of the platforms where the President was questioned about the Nkandla in reference to it as having all signs of corruption, he argued that the former Public Protector's report has no reference to corruption. He further expressed his opinion that people who speak about corruption are political witchhunters. But the question is: Did the former Public Protector have to pronounce Nkandla to be a corrupt incident ad verbatim? Does this mean the absence of the word 'corruption' means it does not exist in this particular case? This section begins with the general definition of the term 'corruption' and further goes on to define my understanding of structural or organisational corruption, which is not an easy task. Corruption is not necessarily an easy phenomenon to define because it varies in nature, depending on its context. Simplistically, political corruption relates to individual or organisational abuse of politically mandated power (individually or collectively) and circumventing consequences 
or preventing legal processes from taking place. Pinto et al., (2008:685) differentiate between corrupt organisations and organisations of corrupt individuals. These authors define an organisation of corrupt individuals as the scaling up of personally beneficial corrupt behaviours to the organisation level. By 'organisation' in this context, the author refers to those entrusted with political obligations by the public; in the judgement of the Constitutional Court, the Chief Justice Mogoeng referred to this as the 'constitutional obligation' (New Agenda 2016). Levine (2005:1) sees organisational corruption as a phenomenon which is spreading widely among a given group of people in such a way that it is entrenched in society. From Levine's assertion, the author identifies in some of what he regards as qualities associated with corruption in the Nkandla controversy or issue from an individual as well as organisational level, in particular egotistical (i.e. someone with an exaggerated self-esteem) impudence and a sense of personal entitlement. It is clear to the public that individual action always impacts on others such as family, general public, business partners, associates and organisations. MacIntyre (1984:148) in his promotion of the ethic of 'virtue' as opposed to the ethic of action emphasises this differently. According to him the virtues are shaped in accordance to the acceptance or internalisation of the ideal of the common good.

This definition would help the reader to make his or her own judgement as to whether Nkandla narrative has what characterises actions as corrupt or not. Public Service AntiCorruption Strategy (PSACS) working definition for corruption is adopted in this article and it reads as follows:

$[\ldots]$ any conduct or behaviour in relation to persons entrusted with responsibilities in public office which violates their duties as public officials and which is aimed at obtaining undue gratification of any kind for themselves or others. (PSACS 2002)

This definition captures the main idea regarding corruption, indeed the Nkandla security upgrades scandal entails almost all elements of corruption as understood by this scholar. For Gerring and Thacker (2004:300), political corruption is understood as 'public official that violates legal or social norms for private or particularistic gain'. Corruption is indeed an anomaly because it takes away from the people what is legally due to them in order to benefit individuals illegally. Given the PSACS definition, it follows that the former Public Protector did not have to pronounce Nkandla the so-called 'security upgrades' as corruption. Although the former Public Protector's report does not contain the concept, it is still regarded as corruption. Corruption by public officials betrays moral ideals of political integrity and undermines efforts to promote a moral culture in a society. In South Africa, there are growing concerns regarding the collapse of the moral fibre which is also referred to in some circles of education, the academic, sociological and political as moral degeneration (de Klerk-Luttig \& van der Walt 2008; Louw 2009). Determined leaders in this country encouraged people to develop a moral culture and work towards moralregeneration. A call to moral regeneration appears to be a direct acknowledgement that morality, which is glue that holds the social orderliness together, is quickly disappearing. As a result, Levine (2005:2) articulates that the attack on rules and norms could be interpreted as the attack on the good; likewise, he posits that individuals either get attached to norms or do away with norms. The Constitutional Court judgement concurs with Levine in that it declares that South Africa's 'constitutional democracy can only be truly strengthened when: there is zero-tolerance for the culture of impunity [...]' (New Agenda 2016:9). For Levine those who fail to get attached to norms are likely 'to develop qualities associated with corruption' (2005:3). It remains deeply ironic that President Jacob Zuma at one time prominently headed the Moral Regeneration Project. This irony gives content to qualities of which Levine gives examples: 'greed, arrogance, a sense of personal entitlement, the idea of virtue as personal loyalty, and the inability to distinguish the common good and personal ends'.

Accordingly, Atkinson and Bierling (2005:1006) emphatically argue that rules may help to shape politicians' behaviour. Similarly, O'Callaghan (1989:444) postulates that once moral [political] leadership decides to put principles aside for casuistry, morality will suffer. Indeed as Waliggo (1996) correctly argues, corruption contradicts the normality in a given society; South Africa's normal running of politics and services has been compromised by the Nkandla issue. Van der Merwe (2001) simply defines corruption as 'the abuse of public office for private gain'. Such private gain is much too evident in the Nkandla project. In addition, Levine (2005:4) identifies a conflict which exists between what he refers to as 'the moral claims of the corrupt and their corrupt conduct'. Levine further contends that the corrupt are unable to 'perceive their corruption as corruption'. Clearly, their understanding of moral norms and accountability are different from those of other rational persons. The Nkandla project has become a governance and ANC problem. It is for this reason the author contends that South Africa will never be the same after Nkandla. The President does not seem to understand the fact that since he received services which could not be legally and morally justified, this constitutes corruption, according to the working definition provided by PSACS 2002. This Atkinson and Bierling (2005) refer to as 'benefiting improperly from public office'. President Zuma had material benefits, which could never be justified constitutionally but Cabinet, and some ANC loyalists and MK veterans continue to justify the spending.

Levine (2005) goes on to contend that corruption also includes efforts to hide the truth. Put differently, corruption consists in maintaining top secrecy for unacceptable practices; as such Gerring and Thacker perceive corruption as 'indicative of governmental performances' (2004:299). There is little doubt that the Minister of Public Services, the Minister of Police, loyalists within the Zuma camp such as the ANC Youth League, the ANC National Executive Committee, the ANC MK veterans and other cabinet ministers in the Zuma administration have failed the country in a big way and continue to do so; firstly by their conceit and denial of any wrongdoing and, secondly, by their new strategy to get out of 
the scandal by shifting blame to lower-ranking government officials and non-political figures. This was made fundamentally clear by the Constitutional Court judgement on the same matter that the President and the National Assembly have the obligation to defend the constitutional democracy of South Africa (New Agenda 2016:6). According to Bivins (2006:29), this constitutes 'moral buck passing' about which he also claims is a rule rather than an exception. It is absurd that a democratic principle of accountability is shifted to lower-ranking government officials, while those burdened with the duty to account get away scot-free. Again, failing to account where accountability is a moral duty is regarded as failing the test of what Kant considered moral obligation on the part of moral agents who are supposed to do so. It is apparently clear that the President is not willing to take full responsibility regarding the Nkandla project by continuously shifting blame to others and consistently claiming ignorance. In this regard, February (2014) suggests that the President has surrounded himself with 'unethical and criminally oriented individuals who hide from him information on matters directly involving him'. Clearly, the attitude of the President, the executive and the ANC National Executive Committee suggest there is no desire to be accountable and transparent regarding the Nkandla project. A particular capacity to respond to a moral call is always taken as given. To emphasise this, Bivins writes:

Moral responsibility assumes a capacity for making rational decisions, which in turn justifies holding moral agents accountable for their actions. [...], in that autonomous rational agents are in principle capable of responding to moral reasons, accountability is a necessary feature of morality. (Bivins 2006:20)

In this regard, Bivins (2006:21) further suggests the following as a formula for determining accountability:

i. If the person is functionally or morally responsible for an action or [decision];

ii. if some harm occurred due to that action or decision, and

iii. if the responsible person had no legitimate excuse for the action.

The remedial action(s) recommended by the Office of the former Public Protector Madonsela (2014) determined that the President was indeed morally responsible; this was further confirmed by the Constitutional Court on Nkandla judgement. According to Mr. Matthew Phosa (2014), parliament's failure to act responsibly in that situation and do the right thing when such pronouncements are made against the ANC, you ask yourself: 'What happened to the ANC?' Clearly, harm resulted from the action in that the action polarised the nation and casted doubt on the ability of President Zuma and parliament to act in the interest of the general public and guided by the rule of law. Therefore, in the context of this article, the author concurs with Bivins that all of the above define the character of the Nkandla project: accountability is not forthcoming. This is another way of disregarding the categorical imperative (CI) of 'not merely using other persons as means to an end'. The author further argues the buck-stops-with-someone in the highest position; in this case, the President and his Cabinet. In its judgement, the Constitutional Court found that the President as the Head of State holds the highest office and as the first citizen occupies an indispensable position for effective governance. In her recommended remedial action, the former Public Protector clearly indicates that the President failed to ask questions regarding the security upgrades which were taking place in his private dwelling. As both the former Public Protector's report and the findings of the Constitutional Court resolved (New Agenda: South African Journal of Social and Economic Policy 2016). It is further argued that holding a person accountable for his or her deeds is an indication of respect awarded to this particular individual. In a same way, a person's avoidance of taking responsibility and accounting for his or her 'political errors' (Atkinson \& Bierling 2005) in moral matters is doing disservice to the public trust over and above self-disrespect.

The author contends that the popular expression 'prevention is better than cure' could be applicable in the moral education of young people, since their moral consciousness or lack thereof will play an important role as they are regarded as future leaders in business and in government. Hence, the Kantian moral theory is proposed as a preventive measure that could help shape the moral fibre of public office bearers in particular. The author argues that Kant's moral theory takes it for granted that a sensible moral culture that is realistic and reasonable is one which can be universalised. For Kant, morality represents an environment in which people as rational beings maturely agree to rational norms and principles which would normalise society in the kingdom of ends.

Perhaps one needs to define the term 'arrogance'. Looked at from a realistic point of view, arrogance has everything to do with the nonchalant attitude of an individual or that of a group; in this sense, arrogance is a display with an attitude of undermining and disrespecting other people. According to Niebuhr (2001:113), actions of organisations are determined not by what individuals do but by their attitude. Therefore, displaying an egotistical attitude could be viewed from an ethical perspective as wrong, in a sense; arrogance is an action which is also subjected to ethical standards. The author opines that arrogance is an attitude which suggests the absence of humility and the refusal to admit to making a bad moral judgement. Taking this further, Cocking (2005:51) posits that 'refusing to consider the reasons put to you that would suggest you're (sic) mistaken is for him regarded as arrogance'. Thus, it is maintained that the claim that person $\mathrm{A}$ is arrogant is a serious ethical statement, which summarises the action(s) of A as morally unacceptable. Further, if B acts from the basis of the power he or she wields, then ones' action lacks morality since his or her action is unreasonable and as such does not reflect the maxim of the will. Acting from the basis of power as is the case in the Nkandlagate involved the abuse of power; this is not ethical. The Nkandla 'security upgrades' controversy clearly indicates that some people do have a sense of moral responsibility while others do not. 


\section{Adopting the categorical imperative for dealing with political situations}

The German philosopher Immanuel Kant (1724-1804) like his predecessors in the field of philosophy focused in certain areas of the discipline and as such is credited with the moral theory known as deontology or Kantian ethics. In his theory, Kant sought a basis for morals by introducing the categorical imperative. As such, deontology as a moral theory takes a form of moral obligation. Kant believes that the morality of human action comes from that which characterised actions as morally binding, that is, a call to duty which comes from within. As such in Kant's ethics, there is a strong relationship between law and duty (Gonsalves 1985:152). Gonsalves further notes that Kant's moral theory is formulated in slightly modified formulations in the form of the CI. There are all-in-all four formulations of the CI. The first formulation is regarded as the general one, which will be given a symbol ' $G$ ', whereas other formulations which are slight modifications would be assigned symbols M1, M2 and M3, respectively. The formulations of the $\mathrm{CI}$ are as follows:

- $\mathrm{G}$ - 'Act only according to that maxim by which you can at the same time will that your actions become a universal law' (Gonsalves 1985:152; Norman 1998:76).

- M1 - 'Act as if the maxim of your action were to become by your will a universal law of nature' (Gonsalves 1985:152; Norman 1998:76)

- M2 - 'So act as to treat humanity, whether in your own person or that of any other, never solely as a means but always as an end' (Gonsalves 1985:152; Norman 1998:76).

- M3 'So act as if you were by your maxims in every case a legislating member in the universal kingdom of ends' (Gonsalves 1985:152; Norman 1998:76).

To begin with, it is obligatory to clarify our understanding of basic concepts which Kant uses in his formulation of the categorical imperative. Kant distinguishes from two kinds of imperatives, namely the hypothetical and categorical. Hypothetical imperative is understood by Kant to have exactly the same meaning as a hypothetical statement. Generally, a hypothetical statement links an antecedent and a consequent action or action-mandate; it is characterised by if-then structure. In the case of a hypothetical imperative, the action which is the object of the imperative is only considered as a means to achieving an end (Wren 2008:32). For example, if you want ' $c$ ' then do ' $b$ '. In this command, there is clearly a condition, which seems plausible in the manner through which the Nkandla project was carried out and continues to be defended by Zuma's political loyalists. Assumingly, a rational agent would not will through the maxim of his or her rationality that the hypothetical imperative be universalised. This suggests that the hypothetical command cannot be regarded as a moral command in a sense that it does not flow from good will or good intention. Contrarily, the categorical imperative in Kant's doctrine is regarded as a moral imperative, because it does not have the antecedent and the consequent structure, that is, there is no condition attached to it. In the categorical imperative, the moral uprightness of an action does not depend on anything else but on the action itself. As such, unlike the hypothetical imperative, the categorical imperative is a product of the moral maxim. What then is the moral maxim in Kant's philosophy?

As elucidated by Balgrie (1982:100), Kant outlines his understanding of the concept maxim, defined as the subjective principle of an action and which according to him is further regarded as that which contains 'practical rule determined by reason'. The concept maxim has all to do with the guiding principles, which govern an agent's action(s). The same idea is explained further by Shaw (2014:55) according to whom a maxim for Kant is a rule on which one acts morally. In a sense, an agent's maxim is the essence on which inner disposition(s) are rooted. In other words, ones' actions are external expression(s) of inner convictions. This is supported by the fact that Kant's ethics emphasise consistency in ones' moral principle(s). In view of that, the categorical imperative and its maxim are meant for rational beings or agents who by their own maxim will for their actions to become the universal law of nature. Accordingly, for Kant the morality of the act is determined not by its consequences but by the moral obligation or a sense of moral duty. Composta (1987:30) identifies three moral imperatives in the CI. Firstly, the idea of universalising ones' action(s); secondly, emphasis on the good will, and; thirdly, respect for humanity. Understood from this point of view, the author encapsulates Kant's doctrine thus: if one cannot consistently universalise his or her actions, such principles and actions fail the test insofar as the categorical imperative is concerned. Actions could be morally accepted if and only if they can be universalised in the kingdom of rational beings. Further, actions which must have universal acceptability are those which flow from good will only. Given this, the author asks: How does Kant understand the concept will? Shaw (2014:54) offers the following explanation: '[by] will Kant meant the uniquely human capacity to act from principle'. As pointed out earlier, the idea of duty dominates Kant's deontology theory; therefore, from the good will flow actions motivated by performing one's duty. Kant argues that actions which are aimed at one performing their duty are thus moral actions. This is because such actions are internalised and therefore performed with freedom; there is no external pressure exerted on the doer from the outside. As such, the internalised observation of law is for Kant self-imposed. In other words, a reasonable person would not will for that which he or she regards unreasonable. O'Callaghan (1989:443) suggests that principles have a role which he outlines as 'patterns of moral decision-making'. Interpreted correctly, this implies that moral principles are criteria for distinguishing right from wrong in any given situation. Understood from this perspective, the moral maxim serves as a source from which individual moral fibre is founded; it is that which gives moral direction. In this way, moral principles are self-imposed and internalised thus bringing about moral order into the life of the individual and the wellness of society. Simply put, moral maxim refers to moral ideals an individual puts up to direct his or her moral life. This further suggests that a person of 
principles and integrity is one that can be trusted to make good moral deliberations.

\section{Applying Kantianism in the Nkandla controversy}

In this regard, the author argues that moral principles make sense strictly in terms of their validity and applicability. Kant's reasoning was that by applying their reasoning, rational human beings could arrive at agreements on moral standards, norms, duties and obligations that were central to a moral and sensible life. Kant further argued that the application of his doctrine could be applied in the kingdom of rational beings consistently and universally. As such, the author examines into the Nkandla issue in terms of its validity and application as advocated by Kantianism. Kant argued strongly that morality among other things depended on humans' ability to advocate for consistency in their action. In his attempt to clarify and simplify his theory, he concluded that a selfless moral individual is he or she who by the maxim of his or her action would universalise the action into a moral law guiding every other rational person anywhere in the world. If a person could consent to his or her action(s) to be regarded as the universal law, then that action is probably a moral one. In other words, any doubt or hesitation even for a second to universalise ones' action(s) suggests a moral problem; put in a different way, an inconsistency insofar as this is concerned poses an ethical problem. Interestingly, President Zuma in his written report to parliament concluded that a policy should be in place, regulating the minimum amount that could be spent on the building or renovation of future presidents' residences. What this suggests in terms of the above-stated formulation of the categorical imperative is an inconsistency. President Zuma on reflecting upon the Nkandla 'security upgrades' cannot will for what happened in his private home to become the law. He does not through the maxim of his undue benefit will that future South African presidents could benefit as he did. This sudden change logically suggests that he must have awakened to a moral realisation that the maxim of the actions through which he benefited cannot be universalised. As much as he may be praised for finally coming to a moral consciousness or realisation that the actions from which he benefited were not praiseworthy, for Kantian ethicists, the lack of consistency on the part of the President remains unimpressive.

In his earlier response to parliament regarding 'security upgrades' which took place at his private residence, President Zuma assured parliament and the nation that government did not build his house but he built it himself using his family resources. Writing on this matter, February (2014) reminds the public of what transpired then by putting it in Jacob Zuma's own words to parliament:

My residence in Nkandla has been paid for by the Zuma family. All the buildings and every room we use in that residence, was built by ourselves as family and not by government.

Therefore, Zuma informed parliament and the entire nation that his family had built its own houses and the State had nothing to do with it. This was clearly deceptive. According to the former Public Protector's report (2014), the President also maintained that he secured a building loan from an undisclosed bank for renovations at his private home (again this was not being truthful). The former Public Protector states in her detailed report that this information could not be verified; in other words, there was no evidence to suggest that this was true (February 2014). On the basis of the categorical imperative and deontology as a moral theory, which advocate for moral obligation and propose that actions which are done from 'duty' are those that are moral, the author through the revelations exposed by the former Public Protector ascertains that the President was not telling the truth about his attempt to evade the Nkandla security upgrades scandal. Putting it in a politically correct way, the President misrepresented facts about extravagant expenditure in his private home at Nkandla. The Constitutional Court also confirmed the former Public Protector's findings that the President failed in his duty to protect the resources of the country (Mogoeng 2016). Shaw (2014:57) contends that some actions are always wrong, and among these he asserts: 'Lying is an example'. Close interpretation and understanding of the principle of 'universalising our actions' in the Kantian ethics regards inconsistency of any action as unethical. Lying to get out of an uncomfortable situation therefore cannot be consistent with what individual would will as universal law. Levine (2005) argues that deception is another way to show contempt and express arrogance towards others. If President Zuma holds that he should tell a lie whenever he is cornered, then it is unreasonable or even impossible to will the maxim of his action to become the universal law. Clearly in Kant's mind the wrongness of actions of those involved in the Nkandla 'security upgrades' rests in the number of inconsistencies which include:

1. Lying repeatedly.

2. Unwillingness to legislate that Nkandla example becomes a moral model on which policy for all other future Presidents must be established.

3. Failure to adhere to 'duty' (thus disregarding the law) by those involved in the Nkandla saga, especially those entrusted with public trust and the nation's resources.

4. Failure to acknowledge 'corruption' on Nkandla saga (this denial that Nkandla epitomises corruption at its best is justified by the fact that the concept is not used by the Public Protector in her report).

The author further argues that as Head of State, the President by virtue of his Office has a moral duty to protect the country and its resources; this idea was further articulated by the Constitutional Court Chief Justice Mogoeng (2016). It contradicts this normality when the President is involved in conduct that compromises the moral and social order of the country he is expected to promote.

Furthermore, any morally questionable action which is done in favour of the President or in order to benefit the President in his capacity as President compromises the dignity of the 
Office and weakens the President. The contempt for moral norms is equally contempt for the ideal moral culture the country is hoping for. In the earlier reaction to parliament on Nkandla, in his attempt to avoid accountability, President Zuma was deceptive about at least three important aspects of the upgrades such as the following:

1. Knowledge about the upgrades which were taking place in his private home.

2. Denial that there was a state resource, which was used to build his private home, claiming that his private home was built by the Zuma resources.

3. He 'secured a loan' from a private bank to renovate his private home.

Taking all these factors into consideration and analysing them from Kant's doctrine, telling a lie in an attempt to avoid taking responsibility is morally wrong. As a matter of fact, Matthew Phosa (2014) openly expressed his views that the President should have taken both political and moral responsibility by resigning. Apparently, Kant through this formulation of the categorical imperative advocates for a moral principle where people respect others and as such refrain from 'using' others for their own selfish purposes. Elucidating the foregoing, Levine (2005:11) refers to treating people in this way as 'sources of needed inputs [...]', that is, using others as objects to be manipulated for personal gain. The deception by the President and those who arrogantly attempted to defend the defenceless and extravagant expenditure of state resources is considered disrespectful to society at large and to the Office of the Public Protector in particular. It was established that Kant grounded his moral theory on the maxim that 'nothing is unconditionally good except for good will' (Norman 1998:72). There cannot be any doubt that there is an absence of such a good will in lying. Lying to the whole nation about a matter as obvious as Nkandla so-called security upgrades is regarded as taking the people for granted. Taking people for granted in Kant's doctrine is morally wrong, it is against the categorical imperative which requires other rational beings to be respected and not be 'used as means to achieving personal ends but be treated as ends in themselves'.

Kant's categorical imperative reference to the universality principle is misunderstood by some as the ethic of the distant future. The author disagrees. In addition, the author argues that the categorical imperative to be an ethic which analyses what goes on here-and-now taking into consideration its future moral implications. By the same token, Wren (2008:32-33) proposes a practical way by means of which the categorical imperative could be understood by an analogy in which human rights are cited as an example. Wren further argues that human rights are universal not because they are conceptually accepted and respected by all cultures around the world but in the sense that they ought to or should be. In other words, the ethical 'ought' has a moral significance (it is the moral ought).

Insofar as the first formulation goes, Wren suggests that a moral maxim is one that could be rationalised consistently to an extent rational moral agents would want adopted by every person. However, Bauman (2009) puts it differently; he asserts that one cannot advocate against a moral order and realistically expect to live in an orderly world. The second formulation, according to Wren, points to the fact that illogical and irrational maxims are morally impossible to universalise and are thus morally untenable. In the third instance, this formulation simply advocates for a moral maxim in which other people are treated as rational moral agents who ought to be respected as human beings which have intrinsic value; that is, people must be treated as ends in themselves and not merely as means to achieving our vested interests or benefits. Treating people as means to an end is equally treating people as tools since tools are used to achieve personal goals. Apparently the idea of rationality emphasised in Kantian ethics should also be understood within Kant's principle of duty.

Finally, Wren suggests the idea of 'legislative rationality' in which an individual's maxim must be acceptable as a norm or law in the kingdom of ends. The latter analysis is of interest in particular to a non-partisan parliament, whereby parliamentarians could respectfully disagree and thus ensure that the maxim through which they act or do things may be acceptable as normal in the kingdom of rational beings. In the author's view, the maxim through which the ruling party and its majority are conducting parliament affairs is morally unacceptable. This is the outcry expressed by Phosa (2014) in his critique of how the ANC used its majority to protect corruption.

A paper of this nature is duty bound to critically look into the Nkandla matter, and its moral implications name the collective duty of politicians to South African society at its entirety. Before this is done, the author begins by giving a definition of the term accountability. By accountability is meant preparedness to take full responsibility for action(s) performed by statesmen and women. President Zuma does not think he did anything wrong; hence, he is adamant and unwavering he was not going to pay. Lately, in a bid to undermine the former Public Protector's recommendation, the President declared that the decision for him to pay or not to pay back the money spent on his private residence is a call that must be made by the Minister of Police. By undermining the former Public Protector, the author is of the opinion that the President is actually undermining the constitution because the Office of the former Public Protector is a constitutional institution; as such, her recommendations must be taken seriously, and this was further supported by the Constitutional Court judgement on Nkandla (Mogoeng 2016). According to Van der Merwe (2001), the abuse of public power could manifest itself in two ways, namely, behavioural and structural, both of which the author contends hold true in the manner Nkandla project continues to be handled.

Atkinson and Bierling (2005) argue that 'political loyalties trump legal requirements of neutrality'. In the Nkandla project, the public have seen some ANC Cabinet Ministers, MK veterans and people held in high esteem doing everything 
in their power to justify the ethical blunder instead of accounting. This kind of behaviour is referred to by Pinto et al. (2008:685) in their title 'Corrupt Organizations or Organisations of Corrupt Individuals'. The President himself attempted to avoid accountability in his initial response to Nkandla security upgrades. Ashforth and Anand (2003) and Anand, Ashforth and Joshi (2004) refer to this behaviour as the normalisation of corruption and acceptance and perpetuation of corruption in organisations. In the author's view, the arrogance displayed could be interpreted as a refusal to acknowledge moral lapse of a worst kind by these structures, and it is certainly a refusal to be accountable and unpreparedness to take moral responsibility for wrong action(s) involved in the Nkandla 'security upgrades' or Nkandla controversy. Ekpo (2007) contends thus:

The concept of power has no concern for ethical moral behaviour because moral bankruptcy is rooted in the acquisition of power and this has given a negative concept to power, for power is all about gain and the capacity to control an [sic] dominate and not for the maintenance of law and order and promotion of common good. (p. 124)

In a different way, the above statement by Ekpo reminds the public all of the popular expression: 'power corrupts and absolute power corrupts absolutely'. The author's main concern in this regard is on political power, and how this has played out by President Zuma after getting into a power position. It is the author's view that the ruling elites possess too much power and use its majority in parliament to betray the ideals which democracy stands for. Building on Levine' assertion that some qualities necessitate association with corruption, I argued earlier that arrogance and a feeling of personal entitlement are qualities which clearly characterise the Nkandla issue. In the author's view, the whole Nkandla matter suggests to the South African society that President Zuma is more deserving than all other Presidents before and after him. This could not be disputed because never before has this happened, and in his response to parliament, the President suggested that there should be a policy in place establishing ground rules about expenditure that ought to be approved for future presidents' private residential renovations. This readily calls to mind the conclusion by Levine (2005:3) that this is the 'ultimate narcissistic fulfilment' in which the goal is to set one apart in exclusion of all others.

\section{Conclusion and recommendations}

Morality is the foundation of good governance and, as such, the ethical 'ought' is a principle which must inform our social order. It is recommended that the Presidency as an institution 'ought' to carefully choose advisors on a moral ground. These should not be just people who are blind loyalists but morally upright individuals who have a moral standing themselves and, thus, able to morally justify political decisions made for and by the office of the President. Furthermore, the author recommends that moral development be part and parcel of the formal programme for politicians who should be accountable for their actions and be held as such by the societal members, especially members who participate actively in the political processes and thus justify the idea of democratisation of their society.

An outline of Kant's doctrine of the categorical imperative and its application to the Nkandla 'security upgrades' was articulated. In order to achieve this and apply the categorical imperative correctly, the four formulations of the categorical imperative were further explained in terms of Kant's notion of maxim, which was defined as the essence or principle within which our actions are founded. The author likewise contended that our maxim insofar as Kant's doctrine is concerned should be universalised. It was further established that in Kant's writing, the maxim is the production of the good will. It was argued why actions of those involved are irrational, and thus morally untenable. It was further argued that actions which cannot be universalised according to Kant or those that are morally inconsistent are unethical. The author stated that performing an act just because the doer wields political power or any form of power for that matter cannot be regarded as reasonable if, following Kant's ethical theory in particular, the categorical imperative is the maxim by means of which the morality of actions is measured. It was established that for Kant, the morality of an action rests on the concept of moral duty; in a sense a moral person for Kant is one who acts from the principle of moral duty and the principle which promotes consistency. In addition, it was further established that moral duty for Kant refers to duty towards self and duty towards others; as such, actions that are intended to advantage an individual at the expense of many or actions performed to please individuals in their personal capacity cannot be regarded as right actions. It stands to reason that such actions should not be performed.

Accountability in this article was understood as a principle by means of which individuals and organisations, especially people entrusted with public trust, are prepared to take responsibility for their actions. The relationship between organisations of corrupt individuals and corrupt organisations was drawn. It was argued that for people entrusted with the duty to account for their actions or the decisions of a moral nature in the state, failing to do so is morally wrong. It was also contended that corruption does undermine many other aspects of governance, especially in cases where those involved are people entrusted with public trust and public resources. Interpreted correctly, there is no justification for corruption in Kant's deontology or doctrine of the categorical imperative.

The author further pointed out that there is lack of accountability on the side of President Zuma, his Cabinet (institutional responsibility) and ANC leadership. It was argued that this lack of accountability is also demonstrated by the continual refusal to accept moral responsibility from a personal point of view by the President as well as structural refusal to account as a collective. It is thus recommended that President Zuma, Cabinet Ministers and their deputies and the entire African National Congress structures should come to a realisation that it is by their preparedness to accept responsibility for the Nkandla blunder that South Africa can 
move forward. This preparedness to accept responsibility must be sincere and the process of remedying the situation transparent. The author posits this is what accountability is all about. The President and his Cabinet have a duty to account to the people of South Africa.

Finally, it is recommended that in order for South Africa to have a sustainable moral fibre, strategies must be put in place wherein politicians of all political structures must be formally educated towards understanding the role of morality in society. Further, the integrity of the Office of the President must be above moral reproach. Introduction of moral education and development earlier on in South African schools and institutions of higher learning is necessary and cannot be ignored, if South Africa is serious about establishing a moral culture which should make sense and could be universalised. The categorical imperative is the core of what the author takes as cognitive development of Kant's moral education. For Kant, the good will and the theory of the CI are necessary conditions for a moral life, which the author maintains should be regarded as the ethical ought for South Africa to achieve its purpose of establishing a sustainable moral culture. It is recommended that political leadership ought to have principles by which they set high moral standards and lead an exemplary moral life. As some have argued, this political and moral responsibility include among others the President taking moral responsibility and resign, impeachment of the President, and a vote of confidence against the President. This is because the Nkandla controversy is a serious matter which has incited views from many different environments such as political, legal, academic, religious and social.

\section{Acknowledgements Competing interests}

The author declares that he has no financial or personal relationships which may have inappropriately influenced him in writing this article.

\section{References}

Anand, V., Ashforth, B.E. \& Joshi, M., 2004, 'Business as usual: The acceptance and perpetuation of corruption in organizations', Academy of Management Executive 18(2), 39-53. http://dx.doi.org/10.5465/AME.2004.13837437

Ashforth, B.E. \& Ananda, V., 2003, 'The normalization of corruption in organizations' Research in Organizational Behaviour 25, 1-52. http://dx.doi.org/10.1016/S0191 3085(03)25001-2

Atkinson, M.M. \& Bierling, G., 2005, 'Politicians, the public and political ethics: World apart', Canadian Journal of Political Science 38(4), 1003-1028. http://dx.doi. org/10.1017/S0008423905040734

Balgrie, D.J., 1982, 'Kant's original categorical imperative as at 1785 ', South African Journal of Philosophy 1(3), 98-105.

Bauman, M., 2009, 'Law and morality', Christian Research Journal 21(3), viewed 22 March 2015, from https://www.equip.org/article/law-and-morality
Bivins, T.H., 2006, 'Responsibility and accountability', in K. Fitzpatrick \& C. Bronstein (eds.), Ethics and public relations: Responsible advocacy, pp. 19-39, Sage, Thousand Oaks, CA.

Cocking, D., 2005, 'Moral arrogance and moral disagreements', The Australian Journal of Professional and Applied Ethics 7(1), 48-54.

Composta, D., 1987, Moral philosophy and social ethics, Urbanian Pontifical University Press, Indianapolis, IN.

De Klerk-Luttig, J. \& van der Walt, J.L., 2008, 'An education strategy for combating moral degeneration in South Africa', Nederduitse Gereformeerde Teologiese Tydskrif 49(3 \& 4), 113-123 September \& December. http://dx.doi.org/10.17570/ ngtt.2008.v49n3.a09

Ekpo, I., 2007, 'Democracy and the need for political ethics in Nigeria', UNESCO World Philosophy Day 3, 124-139.

February, J., 2014, President Jacob Zuma's incomplete response to the Public Protector's report on Nkandla still leaves more questions than answers, Institution for Security Studies, Pretoria.

Gerring, J. \& Thacket, S.C., 2004, 'Political institutions and corruption: The role of Unitarianism and parliamentarianism', British Journal of Political Science 34, 295-330. http://dx.doi.org/10.1017/S0007123404000067

Gonsalves, M.A., 1985, Fagothey's right and reason: Ethics in theory and practice, Times Mirror, St. Louis, MO.

Levine, D., 2005, 'The corrupt organization', Human Relations 58(6), 1-27. http:// dx.doi.org/10.1177/0018726705057160

Louw, J.M., 2009, 'The socio-educational implications of the moral degeneration of South Africa's society: Towards a solution', Unpublished doctoral thesis at the University of South Africa.

Maclntyre, A., 1984, After virtue, University of Notre Dame Press, Notre Dame, IN.

Madonsela, T., 2014, 'Statement by (former) Public Protector Adv. Thuli Madonsela during a media briefing to release the report on an investigation into allegations of impropriety and unethical conduct relating to the installation and of impropriety and unethical conduct relating to the installation and implementation of security measures by the Department of Public Works a KwaZulu-Natal', Office of the Public Protector South Africa, Pretoria.

Massey, S.J., 1995, 'Individual responsibility for assisting the Nazis in persecuting civilians', in N.J. Kritz (ed.), Transitional justice, Vol. 1, 207-216 United States Institute of Peace Press, Washington, DC.

Mogoeng, M., 2016, Constitutional Court of South Africa: Cases CCT 143/15 and CCT 171/15. In the matter Economic Freedom Fighters (Applicant) vs Speaker of the National Assembly and Others [2016] ZACC 11, The Law Society Library, Pretoria.

Nhleko, N., 2015, Minister Nkosinathi Nhleko: Report on Nkandla Security Upgrades, viewed 28 May 2015, from http://www.gov.za/speeches

Niebuhr, R., 2001, Moral man and immoral society: A study in ethics and politics, Westminster John Know Press, Washington, DC.

Norman, R., 1998, The moral philosophers: An introduction to ethics, 2nd edn., Oxford University Press, Oxford.

O'Callaghan, D.F., 1989, 'The meaning of moral principle', in R.P. Hamel \& K.R. Himes (eds.), Introduction to Christian ethics: A reader, pp. 443-453, Paulist Press, New York.

Pinto, J., Leana, C.R. \& Pil, F.K., 2008, 'Corrupt organizations or organizations of corrupt individuals? Two types of organization-level corruption', Academy of Management Review 33(2), 685-704. http://dx.doi.org/10.5465/AMR.2008.324 65726

Phosa, M., 2014, 'The President should have taken both political and mora responsibility by resigning', Eye Witness News, August 21, p. 5.

Republic of South Africa, 2002, Public service anti-corruption strategy, Government Press, Pretoria.

Shaw, W.H., 2014, Business ethics, 8th edn., International Edition, Wadsworth Cengage Learning, Melbourne, Australia.

The Constitutional Court of the Republic of South Africa, 2016, 'The Supreme Court of the Republic's Extract from the ConCourt Judgement on Nkandla', New Agenda: South African Journal of Social and Economic Policy. First Quarter 61, 6-9.

Van der Merwe, S., 2001, Corruption in South Africa: An exploratory discussion, viewed 23 September 2015, from http://www.interfund.org.za/pdffile/volume2_1

Waliggo, J.M., 1996, 'Corruption and bribery - An African problem?' in M. Lejeune, P. Rosemann \& K. Adenauer (eds.), Business ethics in the African context today: Proceedings of the international conference held at Uganda Martyrs University, 9-12 September. Uganda Martyrs University Press, Nkozi, Kampala.

Wren, T., 2008, 'Philosophical moorings', in L.P. Nucci \& D. Narvariz (eds.), The handbook of moral and character education, pp. 11-29. Routledge Taylor and Francis, New York.

Zaleznik, A., 1970, 'Power and politics in organizational life', Harvard Business Review, viewed 2 April 2015, from http://hbr.org/1970/05/power-and-politics-inorganizational-life/ar/1 